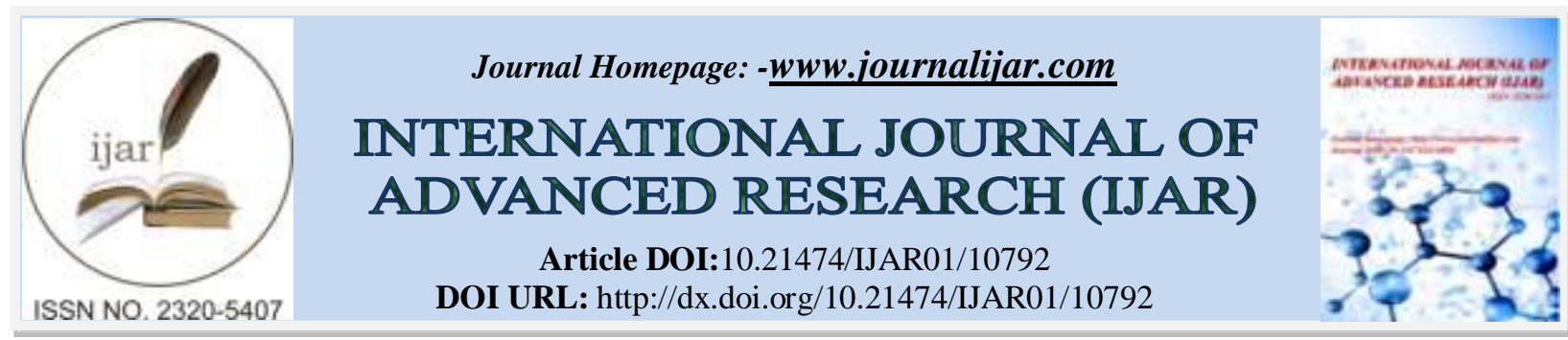

RESEARCH ARTICLE

\title{
THE IMPACT OF INFORMATION SYSTEM QUALITY AND INFORMATION QUALITY ON THE USE OF INFORMATION SYSTEM: CASE OF MOROCCAN RETAIL SECTOR
}

\author{
Zeroual Laila and Zerouali Ouariti Ouafae \\ Research Team in Transport Economics, Information Technologies and Logistics (ERETTLOG), ENCG Agadir, \\ Morocco.
}

\section{Manuscript Info}

............................

Manuscript History

Received: 10 February 2020

Final Accepted: 12 March 2020

Published: April 2020

Key words:-

Information System Quality, Information Quality, Use, Moroccan Retail Sector

\section{Abstract}

The concern of researchers to study the success factors behind information systems is permanent, although it has evolved over the years; it is indeed an active area. Delone and McLean (2003) suggest that the quality of information, the quality of the system, the quality of service and the use and the satisfaction of users can increase performance in different areas. However, several other studies did not support the Delone and McLean study. Thus, the objective of this research is to study this triptych relationship, by showing the effect of information system quality, of information quality on the use of the information system.

Copy Right, IJAR, 2020,. All rights reserved.

\section{Introduction:-}

Due to the information system (IS), a set of data is collected, transformed into information and distributed to users Reix (2011). Users depend a lot on this information to carry out their daily tasks and increase their productivity.In order to support this, the organisation should have a high-quality information system, providing users with information in an easy-to-understand format to improve performance, a high quality of the system lead to high quality of information.

In other words, the quality of information is linked to the quality of the results of the information system and can be described in terms of useful outputs for users. Therefore, it is important to pay attention to the quality of the system in order to improve the quality of the information produced thus promoting usage behavior.

The purpose of this study is to clarify the concepts of the information system quality, information quality and use of the information system. Also explain the relationship between information system quality, information quality and use of the (IS). This article reviews other research. By synthesizing the literature, we hypothesize a positive relationship between the three constructs.

\section{Literature Review and Hypothesis of study:}

This part is organized in four sections. The first section presents the Delon and McLean IS success model. The second section deals with empirical studies related to the relationship between information systems quality and information quality, while summarizing the results of previous research. The third section deals with empirical studies related to the relationship between information systems quality and the usage behaviour of the (IS) while summarizing the results of previous research. And the final section deals with empirical studies related to the 
relationship between information quality and the usage behaviour of the (IS) while summarizing the results of previous research.

\section{IS success model of Delon and McLean:}

Researchers DeLone and McLean (1992) in "Management Information Systems" developed a model for evaluating information systems and its effect on performance. Their model is generally called the information systems success model.

Following the study of around 180 research studies published in 7 journals over the period from 1981 to 1987 , the researchers identified six main dimensions of the success of an information system, namely: the quality of information, the quality of the information system, use, user satisfaction, individual impact and organizational impact.

This model has been the subject of several researches, Seddon (1997) judged that DeLone and McLean would have tried to integrate too many things into their model, confirmed confused and ill-specified. As a result, their basic model was updated in 2003 to respond to criticism, the researchers also included the quality of service dimension to account for the activity of providing assistance to end users, the individual impact and the organizational impact have been replaced by the net benefits which meet the intention of use and user satisfaction.

Indeed, the quality of the system is one of the most studied dimensions of the success of IS, it refers to treatment measures. Meanwhile, the quality of the information is a measure of the production of the information system rather than measuring the quality of the performance of the system, other IS researchers preferred to focus on the quality of the output of the information system, the quality of the information that the system produces.

\section{Information system quality:}

In the literature on information systems (SI), quality is a construction often cited as a reference, but relatively poorly defined (Srinivasan, A, 1985; King, W.R, et al, 1983). For example, for Gorla et al, (2010) the quality of the system represents the quality of information processing which is characterized by: the use of advanced technology, a system with key functions and functionalities and user-friendly software, easy to learn and easy to manage. Seddon (1997) notes that "the quality of the system is related to the presence of bugs in the system, consisting of the user interface, ease of use, quality of documentation, etc.". These definitions focus on the technical characteristics of the system used.

Bailey-Pearson (1983) includes in their studies on user satisfaction a variety of dimensions and they equate the quality of the information system with operational measures such as ease of access, flexibility of the system, system flexibility, system reliability, system integration and response time (Sedera, D et al, 2004).

Also, Gorla et al, (2010) grouped the attributes of system quality into two broad categories: system characteristics from the point of view of the system designer (called system flexibility) and system characteristics from the point of view of the end-user's (called system sophistication that is, using modern technology and provides user-friendly interfaces). Seddon and Kiew (1996) also found in their trajectory analysis that the quality of the information system is an important determinant of overall user satisfaction.

The quality of the information system is considered by several authors (Mason, RO, 1978; Rai, A et al, 2002; Shaw, NG, 2002) as an initial and essential antecedent of the success of the information system represented by the use and user satisfaction (Lee, Y, et al, 2003), its dimensions also represent users' perceptions of interaction with the system over time (R. Ryan Nelson et al, 2005). In this sense, higher quality systems should be seen as easier to use and ultimately more useful and usable.

As DeLone and McLean mentioned when we look at the quality of the system, it pays to think that information is the product of a system and that this system is the information processing system, which suggests that existence of cross effects or interaction between the two concepts. So poor IS quality leads to poor information quality due to irrelevant and incomplete information. However, a good quality information system makes it possible to respond quickly and efficiently to the information needs of users, which leads to relevant and up-to-date information for users, implying a high quality of information. 
The first hypothesis is as follows

Hypothesis 1:

There is a significant, positive relationship between information system quality and information quality.

\section{Use of information system:}

The use is one of the most frequently used variables by researchers in measuring the success of an SI. And given the lack of definition around this variable Burton-Jones and Straub (2005) propose a definition which is based on three elements: user, system, and task, that is, we use a technology a system to accomplish a task. It should be noted that there are two environments of use, voluntary and mandatory, for our case it is the mandatory that interests us since at the level of retail sector the use of IS is a necessity for example store manager cannot carry out his work without IS, so he has no choice but to use it. By emphasizing the task-technology approach.

Indeed, the use of the system lacks definitions and even Delone and McLean did not define it in their research they limited themselves to the level of use, objectives of use... With this vagueness which surrounds the definition of use, several measures are available depending on the researcher's vision, if we consider the use as behavior several researchers have measured it by the duration of use, the frequency of use, and if we consider it as knowledge, they measured it by the level of knowledge absorption, so if we consider it as an effect we use indicators such as the observation of user attitudes at the time of use.We can therefore say that there is an abundance of dimensions, but few researchers justify their choice, which justifies the theoretical lack linked to this variable.

The second hypothesis is as follows

Hypothesis 2:

There is a significant, positive relationship between information system quality and use of IS.

Information quality:

Information quality (IQ) has become a key concern in information systems research (Lee, Y. W et al, 2002), as many researchers consider it an important factor in the success of an information system (Al-Mamary et al, 2014), and is a determinant of its usefulness (Zhou, $\mathrm{H}$ et al, 2014). It is also defined as the extent to which the exchange of information is accurate, timely, complete, relevant and credible (Li \& Lin, 2006; Monczka et al, 1998) reflecting a true picture of the situation.

Delone and McLean's study of variables used to measure the success of information systems revealed that IQ is one of the most used variables, given the particularity of the current context, which is characterized by different sources and an increased need for information for users. For Petersen (1999) good information quality meets the needs of users. Nevertheless, Ackoff (1967) highlighted the problem of information quality, the main failure of which is the abundance of irrelevant and incorrect information, this finding Strong et al, (1997) justified it by the demands of users who change from day to day.

In addition, the quality of the information has been analysed by many researchers in order to identify and classify its dimensions. Huh et al, (1990) defines four dimensions of information quality: accuracy, comprehensiveness, consistency and timeliness. Also other researchers added other parameters such as accuracy, reliability, format, content, consistency, relevance, clarity and completeness (Nelson et al, 2005; Sedera and Gable, 2004; Somers et al, 2003; Delone and McLean, 2003; Sedera and Gable, 2004). Adding to this was the IQ measurement study of Sum and al, (1995) which used other dimensions such as internal/external connectivity and frequency of updating information.

Furthermore, Chopra and Meindl (2016) suggested that information shared between collaborators should be precise, accessible and correct. Thus, Vijayasarathy and Robey (1997) argue that the more precise, timely and complete information, the less misunderstandings and misinterpretations there are between collaborators. Note that better information quality can encourage partners to share more information and can develop a higher level of trust, which will encourage collaboration.

The third hypothesis is as follows

Hypothesis 3:

There is a significant, positive relationship between information quality and use of IS. 
The relationship between information system quality, information quality and the use is illustrated as follows:

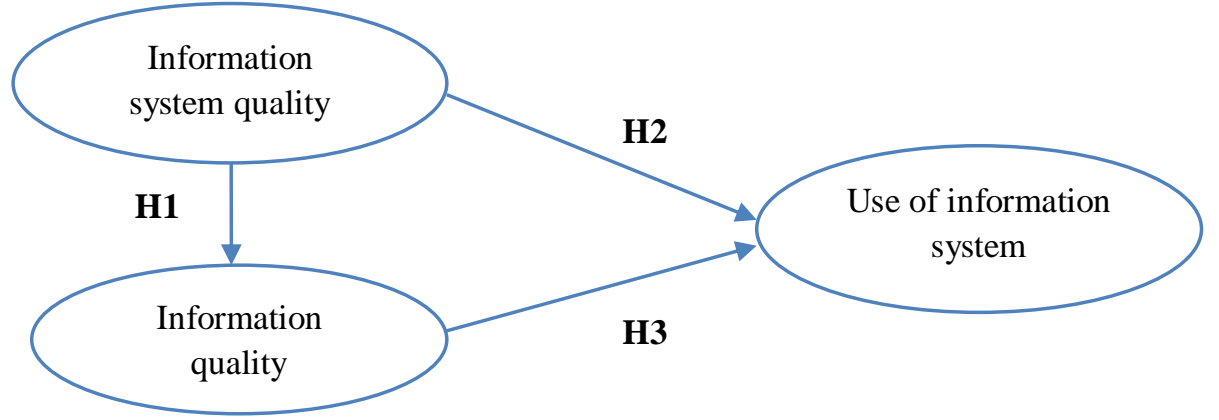

\section{Variables and Items Measured:}

Variables and items measured are listed in $\langle$ Table 1 $\rangle\langle$ Table 2 $\rangle$ and $\langle$ Table 3$\rangle$.

\section{Information quality:}

From our literature review, we identified 5 dimensions of information quality namely: Accuracy, Timeliness, Format, Content and Completeness.And it was measured by 5 items (the items give meaning to the dimensions in question) which are summarized in the following table:

Table 1:- Information quality items.

\begin{tabular}{|c|c|c|c|c|}
\hline Construct & Dimensions & Item & Item no & Reference \\
\hline \multirow[t]{5}{*}{ Information Quality } & Accuracy & $\begin{array}{l}\text { How accurate is the } \\
\text { information circulating in } \\
\text { your LIS? }\end{array}$ & INQ1 & \multirow{5}{*}{$\begin{array}{l}\text { Nelson, R. et al, } \\
\text { (2005). Doll, M.J.et } \\
\text { al, (1994). Gorla, N } \\
\text { et al, (2010). Doll, } \\
\text { M.J (1994). Kahn, } \\
\text { B.K. et al, (2002). } \\
\text { Wang, R.Y et al, } \\
\text { (1996). Moberg CR } \\
\text { et al, (2002). } \\
\text { Feldman M, et al, } \\
\text { (2003). Monczka } \\
\text { RM et al, (1998). } \\
\text { BerryD, et al, } \\
\text { (1994). Metters R et } \\
\text { al, (1997). }\end{array}$} \\
\hline & Timeliness & $\begin{array}{l}\text { How current is the } \\
\text { information you receive? }\end{array}$ & INQ2 & \\
\hline & Format & $\begin{array}{l}\text { How comprehensible is the } \\
\text { information you receive } \\
\text { (exchanged)? }\end{array}$ & INQ3 & \\
\hline & Content & $\begin{array}{l}\text { How useful is the information } \\
\text { you receive (exchanged) in } \\
\text { your daily jobs? }\end{array}$ & INQ4 & \\
\hline & Completeness & $\begin{array}{l}\text { How complete is the } \\
\text { information you receive } \\
\text { (exchanged)? }\end{array}$ & INQ5 & \\
\hline
\end{tabular}

\section{Information system quality:}

Regarding the variable of the quality of the information system, here again we were able to identify, from the literature, five measurement dimensions, namely: Ease of use of the IS, Adequacy of the IS, Reliability of the IS, Rapidity of the IS, Flexibility of the IS. And it was measured by 5 items (the items give meaning to the dimensions in question) which are summarized in the following table:

Table 2:- Information system quality items.

\begin{tabular}{|c|c|c|c|c|}
\hline Construct & Dimensions & Item & Item no & Reference \\
\hline \multirow{4}{*}{$\begin{array}{l}\text { Information System } \\
\text { Quality }\end{array}$} & Ease of use of the & How easy is your SIL to & ISQ1 & \multirow{4}{*}{$\begin{array}{l}\text { Seddon, P et al, } \\
\text { (1997). DeLone, et al, } \\
\text { (2003). Gorla, N et al, } \\
\text { (2010).Sedera, D et al, } \\
\text { (2004). Wang, R.Y et } \\
\text { al, (1997). Nelson, } \\
\text { R.R. et al, (2005). }\end{array}$} \\
\hline & & & & \\
\hline & Adequacy of the IS & $\begin{array}{l}\text { How suitable are your } \\
\text { LISs for your daily } \\
\text { tasks? }\end{array}$ & ISQ2 & \\
\hline & Reliability of the IS & How reliable is your & ISQ3 & \\
\hline
\end{tabular}




\begin{tabular}{|l|l|l|l|l|}
\hline & & SIL? & $\begin{array}{l}\text { Bailey, J.E et al, } \\
\text { (1983). Salmela, H } \\
\text { (1997). }\end{array}$ \\
\cline { 2 - 4 } & Rapidity of the IS & $\begin{array}{l}\text { How quickly does your } \\
\text { LIS respond to an online } \\
\text { request? }\end{array}$ & ISQ4 \\
\cline { 2 - 5 } & Flexibility of the IS & $\begin{array}{l}\text { How flexible is your } \\
\text { SIL? ISQ5 }\end{array}$ & \\
\hline
\end{tabular}

Use of information system:

For the variable of use, here again we were able to identify, from the literature, three dimensions of measurement, namely the Frequency of use, the Relevance of use and the ease of use. And it was measured by three items (the items give "meaning" to the dimensions in question) which are summarized in the following table:

Table 3:- Use items.

\begin{tabular}{|c|c|c|c|c|}
\hline Construct & Dimensions & Item & Item no & Reference \\
\hline \multirow{3}{*}{$\begin{array}{l}\text { Use of Information } \\
\text { System }\end{array}$} & Frequency of use & $\begin{array}{l}\text { How often are you using } \\
\text { IS? }\end{array}$ & US1 & \multirow{3}{*}{$\begin{array}{l}\text { William H. et al, } \\
\text { (2004). Almutairi, H } \\
\text { et al, }(2005) \text {, } \\
\text { Bernard B et al, } \\
(2008) . \quad \text { R. REIX } \\
(1998) .\end{array}$} \\
\hline & Relevance of use & $\begin{array}{l}\text { How relevant is the use of } \\
\text { IS in carrying out your } \\
\text { tasks? }\end{array}$ & US2 & \\
\hline & Ease of use & $\begin{array}{l}\text { How do you assess the } \\
\text { number of different } \\
\text { transactions executed by } \\
\text { your IS? }\end{array}$ & US3 & \\
\hline
\end{tabular}

\section{Research Method:-}

The research design used in this study is quantitative research with the sample were 256 as users of the Information System which in Moroccan retail sector. The sample selection method is a convenience sampling method.

For data analysis, we used Partial Least Square (PLS).

\section{Partial Least Square (PLS)}

The partial least squares (PLS) approach makes it possible to estimate a model of structural equations, and was introduced for the first time by Wold $(1973,1980$ b) who originally developed it for econometrics. Also this approach comes from an ancient theory, of the estimation of least squares based on simple and multiple regressions (Jakobowicz, 2007).

In this study, analysis of research data will be carried out using PLS (SmartPLS version 3.0).

\section{Research Findings:}

Measurement Model / Outher Model Test:

The measurement model, also called outer model in the PLS language, represents the linear relationships assumed between the manifest variables, and is carried out in three evaluation stages: the study of the reliability of internal coherence (Cronbach alpha), convergent validity and discriminant validity.

\section{Reliability Measurement:}

The data collected was subjected to reliability analysis to establish the reliability of the measures. The variables are assessed for reliability using the Cronbach's Alpha in the questionnaires in this study. The value of the reliability coefficient ranges from 0 to 1 . If the coefficient value is close to 1 , then the instrument is reliable.

Table 4:- Provides a summary for all the variables in the analysis.

\begin{tabular}{|l|l|l|l|}
\hline Variables & Items & Cronbach's Alpha & Conclusion \\
\hline Information quality & 5 Questions & $=, 840$ & Reliabel \\
\hline Information system quality & 5 Questions & $=, 891$ & Reliabel \\
\hline use & 3 Questions & $=, 824$ & Reliabel \\
\hline
\end{tabular}


Reliability Testing :

Convergent Validity :

Convergent validity shows how positively a measure is correlated with other measures of the same construct. According to Mbengue et al, (2013) it is an evaluation of the consistency of the measures across different operational modes. It corresponds well to the relationship between the variance of the measurement indicators explained by the latent concept and the total variance. At the time of the evaluation, the researchers take into account the CR Composite reliability index and the AVE Average Variance Extracted index andfactorialscorsloading.

Table 5:- Results of measurements Model- Convergent validity.

\begin{tabular}{|c|c|c|c|c|}
\hline & Items & Loading & A.V.E & C.R \\
\hline \multirow{5}{*}{$\begin{array}{c}\text { Information } \\
\text { Quality }\end{array}$} & INQ1 & 0,864 & \multirow{5}{*}{0,612} & \multirow{5}{*}{0,887} \\
\hline & INQ2 & 0,808 & & \\
\hline & INQ3 & 0,788 & & \\
\hline & INQ4 & 0,719 & & \\
\hline & INQ5 & 0,722 & & \\
\hline \multirow{5}{*}{$\begin{array}{c}\text { Information } \\
\text { System Quality }\end{array}$} & ISQ1 & 0,840 & \multirow{5}{*}{0,698} & \multirow{5}{*}{0,920} \\
\hline & ISQ2 & 0,875 & & \\
\hline & ISQ3 & 0,716 & & \\
\hline & ISQ4 & 0,879 & & \\
\hline & ISQ5 & 0,857 & & \\
\hline \multirow{3}{*}{ Use } & US1 & 0,820 & \multirow{3}{*}{0,739} & \multirow{3}{*}{0,895} \\
\hline & US2 & 0,871 & & \\
\hline & US3 & 0,887 & & \\
\hline
\end{tabular}

Confirmatory factor analysis (CFA) for thismeasurement model was performed.

The result is shown in 〈Table 5>. Each value of Cronbach's alpha, composite reliability, and average variance extracted (AVE) exceed respectively the recommended value of $0.7,0.7$, and 0.5 .

The convergent validity is therefore met.

To go further in our analysis, we move on to discriminatory validity.

\section{Discriminant Validity:}

Regarding discriminant validity, it assumes that the manifest variable must be correlated to its own latent variable as well as the other latent variables and that each latent variable must better explain its own manifest variables. Also utilized to show that latent constructs predict the size of a particular block is better than the size of another block.

Table 6:- Discriminant validity.

\begin{tabular}{|c|c|c|c|}
\hline & INQ & ISQ & USE \\
\hline INQ1 & $\mathbf{0 . 8 6 3}$ & 0.410 & 0.303 \\
\hline INQ2 & $\mathbf{0 . 8 0 9}$ & 0.402 & 0.298 \\
\hline INQ3 & $\mathbf{0 . 7 9 3}$ & 0.398 & 0.331 \\
\hline INQ4 & $\mathbf{0 . 7 1 9}$ & 0.366 & 0.281 \\
\hline INQ5 & $\mathbf{0 . 7 1 7}$ & 0.438 & 0.327 \\
\hline ISQ1 & 0.314 & $\mathbf{0 . 8 4 3}$ & 0.345 \\
\hline ISQ2 & 0.417 & $\mathbf{0 . 8 7 5}$ & 0.383 \\
\hline ISQ3 & 0.288 & $\mathbf{0 . 7 1 0}$ & 0.225 \\
\hline ISQ4 & 0.344 & $\mathbf{0 . 8 8 0}$ & 0.335 \\
\hline ISQ5 & 0.398 & $\mathbf{0 . 8 5 7}$ & 0.400 \\
\hline US1 & 0.251 & 0.255 & $\mathbf{0 . 8 1 5}$ \\
\hline US2 & 0.329 & 0.435 & $\mathbf{0 . 8 7 3}$ \\
\hline US3 & 0.417 & 0.347 & $\mathbf{0 . 8 8 9}$ \\
\hline
\end{tabular}


In table, it can be seen that the indicator correlation value for the construct (latent variable) is higher than the correlation value between indicators and other constructs.

\section{Structural Model / Inner Model Test:}

The inner model describes the relationship between latent variables based on substantive theory. Inner model testing is done to determine the relationship between constructs as hypothesized in this study.

\section{The coefficient of determination of the model $\mathbf{R}^{2}$ :}

The explanatory power of the structural model is evaluated by the coefficient of determination $\mathrm{R}^{2}$ of the endogenous variables, measuring the percentage of the variance of the variable explained by the explanatory variables. Recall that each measurement scale is composed of manifest variables, considered as explanatory variables, allowing to quantify latent variables, considered as explained variables.

Table 7:- R-Square.

\begin{tabular}{|l|l|}
\hline & R-Square \\
\hline Information Quality & 0,269 \\
\hline Information System Quality & 0,403 \\
\hline Use & 0,295 \\
\hline
\end{tabular}

Chin, (1998) suggests that the $\mathrm{R}^{2}$ values of $0.67,0.33$ and 0.19 in the PLS-SEM can be considered as high, moderate and low respectively. The R- square value indicates that the model is good.

\section{Hypothesis Testing:}

The table below shows the statistical summary results to all hypothesis testing.

Table 8:- The Results of Hypotheses Testing.

\begin{tabular}{|c|c|c|c|c|}
\hline Hypothesis & $\begin{array}{c}\text { Beta } \\
\text { Path Coefficient }\end{array}$ & T-Value & P-Value & $\begin{array}{c}\text { Hypothesis } \\
\text { Status }\end{array}$ \\
\hline $\begin{array}{c}\text { H1- Information system } \\
\text { quality => information } \\
\text { quality }\end{array}$ & 0,518 & 11,522 & $0,000^{* *}$ & Supported \\
\hline $\begin{array}{c}\text { H2- Information system } \\
\text { quality => Use of IS }\end{array}$ & 0,081 & $\mathbf{1 , 2 3 4}$ & $\mathbf{0 , 2 1 8}$ & No Supported \\
\hline $\begin{array}{c}\text { H3- Information quality } \\
\text { => Use of IS }\end{array}$ & 0,302 & 3,609 & $0,000^{* *}$ & Supported \\
\hline
\end{tabular}

$+\mathrm{P}<, 15 ; * \mathrm{P}<, 10 ; * * \mathrm{P}<, 05 ; * * * \mathrm{P}<, 01 / \mathrm{NS}:$ non significatif

The results for $\mathrm{H} 1$ show that there is a significant positive relationship between information system quality and information quality $(\mathrm{t}=11,522 \mathrm{p}=0.000)$. Thus, $\mathrm{H} 1$ is accepted.

The results in Table for $\mathrm{H} 2$ show that there is no a significant positive relationship between information system quality and use $(\mathrm{t}=1,234 \mathrm{p}=0.218)$. Thus, $\mathrm{H} 2$ is no accepted.

Lastly, Hypotheses testing for $\mathrm{H} 3$ also show that there is significant positive relationship between information quality and use $(\mathrm{t}=3,609, \mathrm{p}=0.000)$. Thus, $\mathrm{H} 3$ is also supported by the testing.

\section{Conclusion:-}

Based on testing the hypothesis, the results of the analysis and discussing the results of the study, then conclusions can be put forward as follows: 
According to the statistical processing carried out, it appears that the relationship between information system quality and its use is not significant. We find that the information system quality has no effect on use, so there is no positive relationship between the two variables.

The non-confirmation of this research hypothesis can be justified by the particularity of the retail sector, which is characterized by a large quantity of the information exchanged, which requires the establishment of an IS for the processing and sharing of this information. Use in this case is mandatory, users do not have the choice to use it or not, it is imposed. Our respondents felt compelled to use the information system, regardless of its quality.

The context of the research could play a role in the non-confirmation of this research hypothesis.

After statistical processing, it appears that the relationship between information system quality and information quality is significant. We note that the quality of information system has a positive and significant effect on information quality.

The results of this study corroborate the results of similar studies in other contexts and sectors, which call for greater emphasis on the quality of the information system in order to improve the quality of information.

Our respondents in the retail sector consider the ease of use of the IS, the adequacy of the IS with their functional needs, the reliability of the IS, its speed in order execution and its flexibility, as key factors that positively impact the quality of information. It should be noted that the notion of the reliability of the system is assessed as the fifth and last dimension of the quality of the IS. This means that it is not one of the qualities expected by users, in other words the absence of failures and bugs is an obvious expectation.

Improved system quality provides reliable, accurate and up-to-date information content. Indeed, as long as the quality of the system is good, the more it increases the quality of the information exchanged.

The Delone and McLean study found that the quality of information is one of the most interesting variables tested and most frequently used, given the specificity of the current economic environment, which is characterized by the increased need for information for users.

The important thing for our respondents is to have accurate, up-to-date, complete information with useful content and in an understandable format, as they hope to find information that will improve their decision-making.

In terms of dimensions of information quality, information accuracy and timeliness are the two most important dimensions for users to respond with agility (the right information at the right time). So that users can quickly understand and process information for their own purposes.

In short, user-generated quality information enables users to access superior resources and encourage the use of information system.

\section{Rreference:-}

1. Ackoff, R. L. (1967). Management Misinformation Systems.Management Science, 14(4), B-147-B-156. doi:10.1287/mnsc.14.4.b147.

2. Al-Mamary, Y. H., Shamsuddin, A., Hamid, A., \&Aziati, N. (2014). The role of different types of information systems in business organizations: A review. International Journal of Research (IJR), 1(7).

3. Bailey, J. E., \& Pearson, S. W. (1983).Development of a Tool for Measuring and Analyzing Computer User Satisfaction.Management Science, 29(5), 530-545. doi:10.1287/mnsc.29.5.530.

4. Burton-Jones, A. (2005). New Perspectives on the System Usage Construct. Thèsed'habilitation. Georgia State University: Atlanta, GA.

5. Chin, Wynne W..(1998). Issues and Opinion on Structural Equation Modeling. MIS Quarterly, (22: 1).

6. Chopra, S., \& Meindl, P. (2016). Supply Chain Management: Strategy, Planning, and Operation (6e éd.). Pearson.

7. DeLone, W. H., \&McLean, E. R. (1992). Information Systems Success: The Quest for the Dependent Variable. Information Systems Research, 3(1), 60-95. doi:10.1287/isre.3.1.60. 
8. DeLone, W. H., \&McLean, E. R. (2003). The DeLone and McLean Model of Information Systems Success: A Ten-Year Update. Journal of Management Information Systems, 19(4), 9-30. doi:10.1080/07421222.2003.11045748.

9. Gorla, N., Somers, T. M., \& Wong, B. (2010). Organizational impact of system quality, information quality, and service quality.The Journal of Strategic Information Systems, 19(3), 207-228. doi:10.1016/j.jsis.2010.05.001.

10. Huh, Y., Keller, F., Redman, T., \& Watkins, A. (1990). Data quality.Information and Software Technology, 32(8), 559-565.doi:10.1016/0950-5849(90)90146-i.

11. Jakobowicz, E. (2007). Contributions aux modèles d'équations structurelles à variables latentes. Thèse de doctorat en informatique. Conservatoire National des Arts et Métiers Paris.

12. King, W. R., \& Epstein, B. J. (1983).Assessing information system value: an experimental study.Decision Sciences, 14(1), 34-45. doi:10.1111/j.1540-5915.1983.tb00167.x.

13. LEE, Y. W., \& STRONG, D. M. (2003).Knowing-Why About Data Processes and Data Quality.Journal of Management Information Systems, 20(3), 13-39. doi:10.1080/07421222.2003.11045775.

14. Lee, Y. W., Strong, D. M., Kahn, B. K., \& Wang, R. Y. (2002). AIMQ: a methodology for information quality assessment. Information \& Management, 40(2), 133 146.doi:10.1016/s0378-7206(02)00043-5.

15. Li, S., \& Lin, B. (2006). Accessing information sharing and information quality in supply chain management. Decision Support Systems, 42(3), 1641-1656. doi:10.1016/j.dss.2006.02.011.

16. Mason, R. O. (1978). Measuring information output: A communication systems approach.Information\& Management, 1(4), 219-234. doi:10.1016/0378-7206(78)90028-9.

17. Mbengue, A., \&Sané, S. (2013). Capacité d'apprentissage organisationnel : analyse théorique et étude empirique dans le contexte des équipes de projets d'aide publique au développement. Canadian Journal of Administrative Sciences / Revue Canadienne Des Sciences de l'Administration, 30(1), i-xvi. doi:10.1002/cjas.1240.

18. Monczka, R. M., Petersen, K. J., Handfield, R. B., \&Ragatz, G. L. (1998). Success Factors in Strategic Supplier Alliances: The Buying Company Perspective. Decision Sciences, 29(3), 553-577. doi:10.1111/j.15405915.1998.tb01354.x.

19. NELSON, R. R., TODD, P. A., \& WIXOM, B. H. (2005). Antecedents of Information and System Quality: An Empirical Examination Within the Context of Data Warehousing. Journal of Management Information Systems, 21(4), 199-235. doi:10.1080/07421222.2005.11045823.

20. NELSON, R. R., TODD, P. A., \& WIXOM, B. H. (2005). Antecedents of Information and System Quality: An Empirical Examination Within the Context of Data Warehousing. Journal of Management Information Systems, 21(4), 199-235. doi:10.1080/07421222.2005.11045823.

21. Petersen, K.J. (1999). The effect of information quality on supply chain performance: an inter-organizational information system perspective. Thése de doctorat: Michigan State University, East Lansing, MI. Stank, T.P.,

22. Rai, A., Lang, S. S., \& Welker, R. B. (2002). Assessing the Validity of IS Success Models: An Empirical Test and Theoretical Analysis. Information Systems Research, 13(1), 50-69. doi:10.1287/isre.13.1.50.96.

23. Reix, R., Fallery, B., Kalika, M., \& Rowe, F. (2011).Systèmes d'information et management (6e éd.). Vuibert.

24. Seddon, P. B. (1997). A Respecification and Extension of the DeLone and McLean Model of IS Success. Information Systems Research, 8(3), 240-253. doi:10.1287/isre.8.3.240

25. Seddon, P., \& Kiew, M.-Y.(1996). A Partial Test and Development of Delone and McLean's Model of IS Success.Australasian Journal of Information Systems, 4(1). doi:10.3127/ajis.v4i1.379.

26. Sedera, D., Gable, G., (2004). A factor and structural equation analysis of the enterprise systems success measurement model. In: Appelgate, L., Galliers, R., DeGross, J.I. (Eds.), Proceedings of the Twenty-Fifth International Conference on Information Systems. Association for Information Systems, Washington, DC, USA, p. 449.

27. Shaw, N. (2002). Capturing the Technological Dimensions of IT Infrastructure Change: A Model and Empirical Evidence. Journal of the Association for Information Systems, 2(1), 1-35. doi:10.17705/1jais.00020.

28. Somers, T. M., Nelson, K., \&Karimi, J. (2003). Confirmatory Factor Analysis of the End-User Computing Satisfaction Instrument: Replication within an ERP Domain. Decision Sciences, 34(3), 595-621. doi:10.1111/j.1540-5414.2003.02428.x.

29. Srinivasan, A. (1985). Alternative Measures of System Effectiveness: Associations and Implications. MIS Quarterly, 9(3), 243. doi:10.2307/248951.

30. Strong, D. M., Lee, Y. W., \& Wang, R. Y. (1997).10 potholes in the road to information quality.Computer, 30(8), 38-46. doi:10.1109/2.607057. 
31. Sum, C.-C., Yang, K.-K., Ang, J. S. K., \&Quek, S.-A. (1995). An analysis of Material Requirements Planning (MRP) benefits using Alternating Conditional Expectation (ACE). Journal of Operations Management, 13(1), 35-58. doi:10.1016/0272-6963(95)00005-d.

32. Vijayasarathy, L. R., \& Robey, D. (1997). The effect of EDI on market channel relationships in retailing. Information \& Management, 33(2), 73-86. doi:10.1016/s0378-7206(97)00029-3.

33. Wold, H. (1973). Nonlinear Iterative Partial Least Squares (NIPALS) Modelling: Some Current Developments. Multivariate Analysis-III, 383-407. doi:10.1016/b978-0-12-426653-7.50032-6.

34. Wold, H. (1980). Model Construction and Evaluation When Theoretical Knowledge Is Scarce.Evaluation of Econometric Models, 47-74. doi:10.1016/b978-0-12-416550-2.50007-8.

35. Zhou, H., Shou, Y., Zhai, X., Li, L., Wood, C., \& Wu, X. (2014). Supply chain practice and information quality: A supply chain strategy study. International Journal of Production Economics, 147, 624-633. doi:10.1016/j.ijpe.2013.08.025. 